\title{
FLUCTUATION OF THE DYNAMIC LOAD NATURE IN THE POWER TRANSMISSION TRAIN
}

\author{
Milanko Damjanović, Vladimir Popović, Sreten Simović
}

Original scientific paper

This paper analyses the impact of the selected parameters: operating mode, design parameters and condition of power transmission system onto the dynamic load of some on its components. Apart from analytical considerations, we also offer the experimental results related to the influence of the operating mode parameters and the condition of power transmission train system onto the torque of a passenger's car axle-shaft. On the basis of the theoretical and experimental research, we drew some conclusions related to the impact of some parameters on the power transmission load. Furthermore, we have given the comparative study of the used models and researching methods.

Keywords: clearance; load; mathematical model; power transmission; vehicle

Utjecaj parametara na dinamička opterećenja prijenosnika snage motornih vozila

Izvorni znanstveni članak

U ovom se radu analizira utjecaj parametara: režima rada, konstrukcijskih parametara i parametara stanja prijenosnika snage na dinamičko opterećenje pojedinih njegovih elemenata. Pored analitičkog razmatranja, dani su i rezultati eksperimentalnog ispitivanja utjecaja parametara režima rada i stanja prijenosnika na vrijednost momenta poluvratila jednog putničkog vozila. Na osnovu teorijskih i eksperimentalnih ispitivanja doneseni su zaključci o utjecaju parametara na opterećenje elemenata prijenosnika snage. U radu su također prikazane i usporedbe između korištenih modela i metoda ispitivanja.

Ključne riječi: matematički model; opterećenje; prijenosnik snage; vozilo; zazor

\section{Introduction}

Vehicle power transmission systems are complex functional and constructive systems which have to sustain a load exerted by both engine and surface.

The structural overview of a vehicle power transmission system can be seen in Fig. 1.

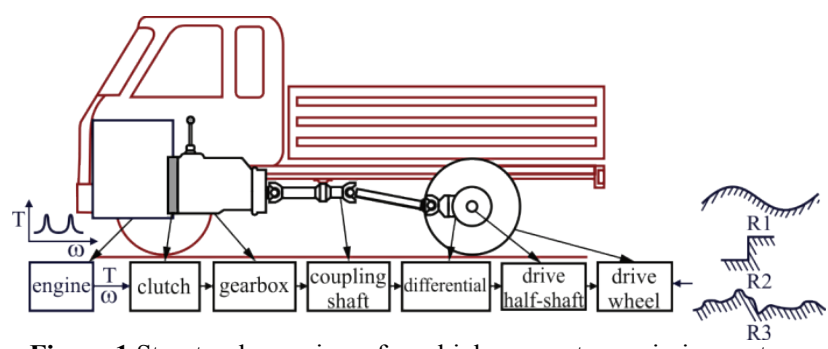

Figure 1 Structural overview of a vehicle power transmission system; R1 - surface (general case), R2 - stair-step obstacle, R3- random shape surface irregularities

These loads create the resulting load with two main components: quasi-static and dynamic one.

The quasi-static loads are slowly changing, random loads with a frequency not higher than in elasto-inertial system.

The value and the character of the dynamic load of transmission elements depend on an external load, structure and design parameters of the transmission as a system, Fig. 2. Beside this, the dynamic load of transmission elements is affected by the condition of the transmission, i.e. the value of the clearance between particular elements. The clearance in the connection between the elements is due to their use, i.e. wear and tear. Moreover, there are changes of physical-mechanical properties of particular elements, such as the decrease in a surface hardness.

Some of these processes, such as: deformities, wear, tear and corrosion occur at the surface of the elements, while the processes related to material weakening occur inside the elements.

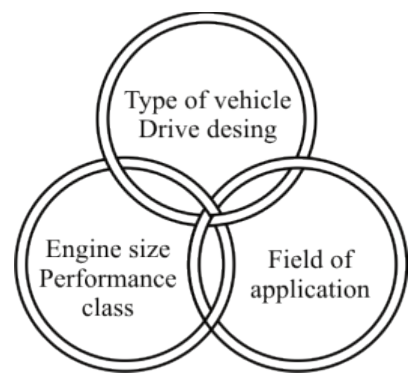

Figure 2 Specification factors for transmission format and design [1]

During the operation of a power transmission system, all the above-mentioned loads are permanently present. The intermittent loads on the power transmission system are effectuated through a clutch (on/off), brakes, transmission break and power transmission system while changing gears.

The part of the system transmitting the power undergoes the changes during the gear change. Consequently, this process changes the dynamic parameters, rigidity and system torque of inertia, causing the change in an element load.

In the majority of the approaches, the elaboration of the load analysis is performed in a way that the processes of the loading of a power transmission train from various impacts can be considered to be independent. According to this, the functions or group of functions of the load distribution for each individual impact are set. This enables analysing and setting of the dependences of the process of loading on each influential component, what makes an opportunity to extract the processes with smaller impacts and, after that, their exclusion from the processing of the load regime.

When speaking about a vehicle power transmission system, depending on the manner of driving, there may be 
significant loads, for instance during the intensive breaking, without the separation of a clutch, what may cause the failure of power transmission system elements. Furthermore, if the vehicle passes over an uneven surface, the load may constantly vary, what can cause a significant damage to the vehicle construction and cause a dangerous situation.

While determining the influence of parameters on the dynamic load of the vehicle transmission system elements, the basic task is to form a mathematical model of a vehicle transmission system.

\subsection{Literature survey}

According to the insight into the reference literature, it can be stated that the impact of the parameters, operational mode, design parameters and parameters of state of power trains on the dynamic loads, is researched insufficiently.

Particularly, the impact of the state of power transmission system is researched insufficiently, namely the values of the clearance in connections of elements on the dynamic loads of the vehicle's power transmission system.

The paper [19], where the occurrence of a clearance in a mechanic power transmission, made of a coupling, shaft and a back gear, is especially important. However, the presence of the clearance in this paper is considered from the standpoint of the impact on the regulation process, namely the choice of the regulator, rather than on the dynamic load of the elements of the power train.

The distribution of the loads on the system elements for the power transmission in motor vehicles, not considering the change of the state of elements, i.e. the presence of the clearance in the connections of elements is given in literature [12]. Also, literature gives the characteristic periods in the development of the methods of calculation of the system elements for the power transmission in motor vehicles and the ways of setting of competent loads.

The literature [11] gives the experimentally obtained results of loads and stresses in some elements of the power transmission in motor vehicles initiated by the triggering of an actuating generator and the irregularities of the surface. For the dynamic behaviour of the power train in motor vehicles, the linear model is given, as a system with five concentric masses, whose behaviour is described in the form of differential equations, in which the impact of an external load is not included.

The dynamic load of the power transmission in commercial vehicles due to the road surface irregularities is analysed in the reference literature [18].

In the reference literature [14] the power transmission in motor vehicles is reduced to the two-mass torsion model, thence the load in the elastic connection of two masses is analysed, in case where there is no damping in the system. Also, for the elastic torsion model with two masses, the dynamic load of an elastic connection for the case when there is a clearance in the system, and its impact on the dynamic load of the elastic connection is assumed on the basis of the starting conditions.

The impact of the clearance on the dynamic loads of the power transmission is mostly studied using the two- mass model for the lifting of ballast for hoisting devices and the power transmission for the horizontal motion of a crane.

For hoisting devices (cranes), this model is used for the purpose of illustrating and studying the dynamics of the load hoisting mechanism as well as of the mechanism for a horizontal movement of a crane (hoisting device) or a truck $[4,5]$. Also, the reference papers $[6,7]$ provide some ways for the determination of the dynamic load of cranes, but these papers do not take into account the parameters of elements'condition.

The references [8, 9] give a vehicle model for analysing the possibility of a speed change in order to reduce fuel consumption, which includes the model of the power transmission. The paper [10] provides an analysis of a dynamic load rotor-bearing system.

\section{Linear power transmission model}

Motor vehicle transmission system elements are dominantly loaded by torsion, thence it is necessary to form a torsion oscillation mathematical model in order to determine their load.

In general case, the model of damped torsional oscillations of the power transmission from $\mathrm{n}$ rotation masses can be written in the form of the matrix equations, $[2,3]$ :

$$
\boldsymbol{J} \cdot\{\ddot{\varphi}\}+\boldsymbol{B} \cdot\{\dot{\varphi}\}+\boldsymbol{C} \cdot\{\varphi\}=\{T\},
$$

where: $\boldsymbol{J}, \boldsymbol{B}, \boldsymbol{C}$ are the matrices of inertia, damping and rigidity ( $n \times n$ dimensions); $\{\ddot{\varphi}\},\{\dot{\varphi}\},\{\varphi\}$ are the vectors of an angular acceleration, angular speed and angular positions of the centres of rotation masses $(n \times 1$ dimensions); $\{T\}$ is the vector of external exciting torques, originating from the engine and motion resistance $(n \times 1$ dimensions $)$.

The solution of the matrix Eq. (1) with multiple masses is analytically very complex, especially for more complex functions of the excitement stemming from an engine and surface. Therefore, in these cases, we have to numerically solve a system of equations, i.e. to simulate the dynamic behaviour of the power transmission.

However, in order to study the dynamic behaviour of the power transmission, we may also use an elasto-inertial system with two masses.

The general elasto-inertial torsion model with two masses is shown below in Fig. 3 [2, 3].

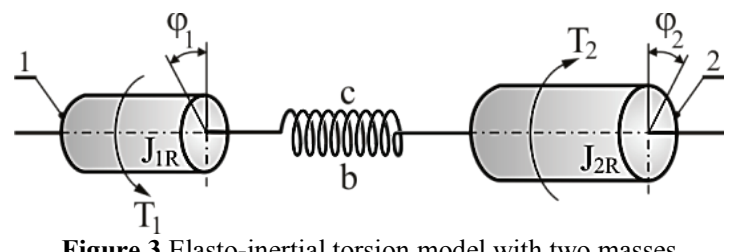

Figure 3 Elasto-inertial torsion model with two masses

The symbols in Fig. 3 have the following meanings: 1 - mass of the drive part of the system, 2 - driven mass, $J_{1}$ reduced inertia torque of the masses of the drive part of the system, $J_{2}$ - reduced inertia torque of the masses of the driven part of the system, $T_{1}$ - drive torque, $T_{2}$ - load 
torque which may be either constant or variable (depending on the system position, time or speed), $b$ damping, $c$ - reduced rigidity of the elastic system parts, $\varphi_{1}$ - angular position of the centre of the rotational mass of the drive part of the system, $\varphi_{2}$ - angular position of the centre of the rotational mass of the driven part of the system.

The elasto-inertial torsion system with two masses enables us to get the closed form solution, which is particularly convenient for the analysis.

Additionally, one can use a different elasto-inertial torsion system with two masses in order to determine the maximum dynamic load of a vehicle power transmission system $[11,12,13]$.

The differential equations of the motion of this system in the warm-up phase are:

$$
\begin{aligned}
& J_{1 R} \cdot \ddot{\varphi}_{1}+b\left(\dot{\varphi}_{1}-\dot{\varphi}_{2}\right)+c\left(\varphi_{1}-\varphi_{2}\right)=T_{1}, \\
& J_{2 R} \cdot \ddot{\varphi}_{2}-b\left(\dot{\varphi}_{1}-\dot{\varphi}_{2}\right)-c\left(\varphi_{1}-\varphi_{2}\right)=-T_{2} .
\end{aligned}
$$

On the basis of the Eq. (2), and ignoring the damping $(b=0)$, where the initial conditions are equal to zero: $t=$ $0, T_{\mathrm{C}}=0, \mathrm{~d} T_{\mathrm{C}} / \mathrm{d} t=0$ and constant torques $T_{1}$ and $T_{2}$, the torque in the elastic connection $T_{\mathrm{C}}=c \cdot\left(\varphi_{1}-\varphi_{2}\right)$ is given by the expression, [14]:

$$
T_{\mathrm{C}}(t)=T_{\mathrm{C} 0} \cdot(1-\cos (p \cdot t)),
$$

where: $T_{\mathrm{C} 0}=\left(J_{1 R} \cdot T_{2}+J_{2 R} \cdot T_{1}\right) /\left(J_{1 R}+J_{2 R}\right)$ constant torque component, $\quad p=\sqrt{\frac{c \cdot\left(J_{1 R}+J_{2 R}\right)}{J_{1 R} \cdot J_{2 R}}}$ circular frequency of two mass system oscillations.

The period of a natural mode is:

$T_{p}=\frac{2 \pi}{p}$

In reality, the change of the operative mode, i.e. the drive torque $T_{1}$ and resistance torque $T_{2}$ do not occur instantaneously, but within the definite time $t_{0}$.

In general case, the linear increase of the torque $T_{1}$ with the time $t_{0}$ can be described in the following manner:

$$
T_{1}(t)=\left\{\begin{array}{l}
T_{10} \cdot \frac{t}{t_{0}}, 0 \leq t<t_{0} \\
T_{10}, \quad t \geq t_{0}
\end{array}\right.
$$

The values of the dynamic load in an elastic connection depends on a drive torque increase rate $T_{1}$ and system oscillatory characteristics, which are defined through the load coefficient $\lambda=t_{0} / T_{p}$.

The increase of dynamic loads in an elastic connection, Fig. 3, is represented through the dynamic coefficient, [14]:

$$
K_{\mathrm{D}}=1+\frac{\sin (\pi \cdot \lambda)}{\pi \cdot \lambda}
$$

The chart of dynamic coefficient changes, depending on load parameters, is given in Fig. 4 [14].

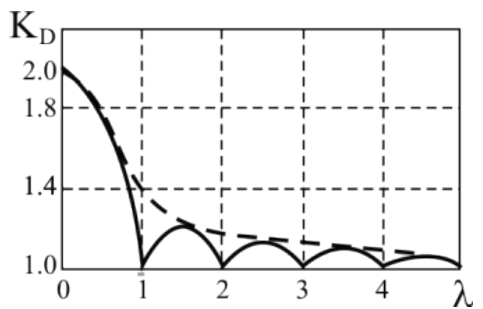

Figure 4 Dynamic coefficient change chart

For the value $\lambda>0,5$, the dynamic coefficient is:

$$
K_{\mathrm{D}}=1+\frac{1}{\pi \cdot \lambda}
$$

which is shown in Fig. 4 as a dashed line.

With an instant increase of the torque $T_{1}$, the dynamic coefficient is $K_{\mathrm{D}}=2$.

\section{Non-linear power transmission model}

A more precise analysis of the impact of parameters onto power transmission elements may be carried out on the basis of a non-linear model which includes a system condition, i.e. the existence of a clearance in gear pairs, clutches, universal joints and other connection elements.

The non-linear transmission model includes the presence of a clearance in the connections between particular transmission elements. The insensitivity zone is the "dead" zone, i.e. the mechanism idle speed.

If there is a clearance in the element's connections in the particular phases of mass movements, it creates the break of a kinematic chain followed by the collision of masses, thus creating additional loads. Because of this, element dynamic loads significantly increase and may reach the values several times higher than the static loads originating from a resistance force.

The non-linear clearance characteristic with the insensitivity zone is shown in Fig. 5 [5].

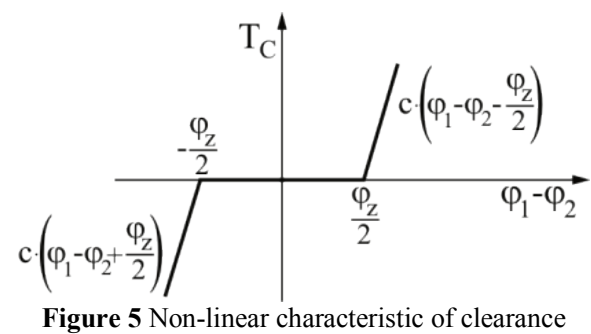

The torsion torque in the elastic connection with clearance is:

$$
T_{\mathrm{C}}=\left\{\begin{array}{lr}
c \cdot\left(\varphi_{1}-\varphi_{2}-\frac{\varphi_{z}}{2}\right), & \frac{\varphi_{z}}{2} \leq \varphi_{1}-\varphi_{2} \\
0, & -\frac{\varphi_{z}}{2} \leq \varphi_{1}-\varphi_{2} \leq \frac{\varphi_{z}}{2} \\
c \cdot\left(\varphi_{1}-\varphi_{2}+\frac{\varphi_{z}}{2}\right), & \varphi_{1}-\varphi_{2} \leq-\frac{\varphi_{z}}{2}
\end{array}\right.
$$


On the basis of the power transmission system structure shown in Fig. 1, we gave a non-linear model of this elasto-inertial system in Fig. 6, what enabled us to set up a simulation model by connecting the particular elements according to the order in the real analysed vehicle.

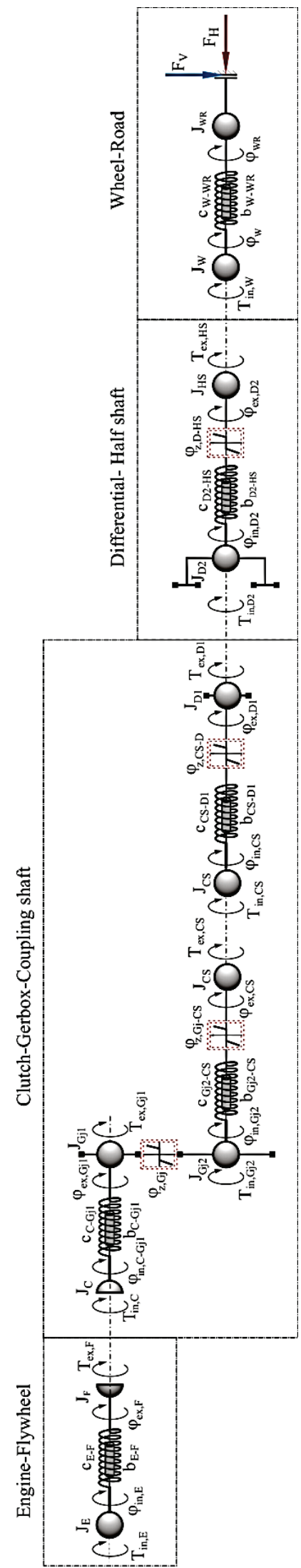

Figure 6 Model of the elasto-inertial system for vehicle power transmission system with clearance between connection elements
The symbols in Fig. 6 have the following meaning: $T$ - torque, $J$ - inertia torque, $\varphi$ - angular position, $\varphi_{z}$ clearance, $F_{\mathrm{V}}$ - external vertical load, $F_{\mathrm{H}}$ - external horizontal load.

Fig. 6 contains the system components characterised by the input/output parameters connected through the appropriate equations.

Both for a linear and non-linear model, we may use the elasto-inertial torsion model with two masses and a clearance between them. With the two mass models, the mass reduction is performed before and after the referential elastic connection for which we seek the load function. The first mass is the drive and the second the driven one.

The elasto-inertial torsion model with two masses and a clearance is shown in Fig. 7 [2, 3].

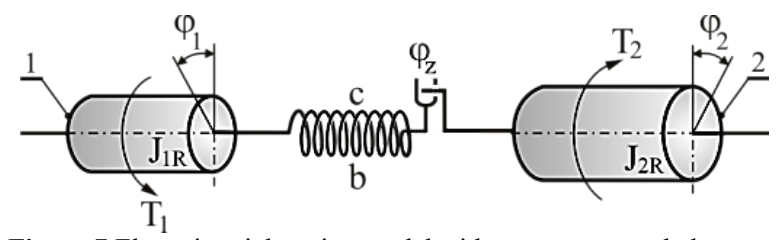

Figure 7 Elasto-inertial torsion model with two masses and clearance

The movement of masses through a clearance may be divided into multiple phases. Having in mind [2, 15], it can be divided into five phases.

The maximum value of a torque in the elastic connection in the operating mode $\left(T_{1}, T_{2}\right)$, construction parameters $\left(c, J_{1 R}, J_{2 R}\right)$ and condition parameters $\left(\varphi_{z}\right)$ of the power transmission is, $[2,15]$ :

$T_{\mathrm{C}, \max }=\frac{J_{1 R} \cdot T_{2}+J_{2 R} \cdot T_{1}}{J_{1 R}+J_{2 R}} \cdot\{1+\sqrt{1+A \cdot G}\}$,

where:

$A=\frac{J_{1 R}+J_{2 R}}{\left(J_{2 R} \cdot T_{1}+J_{1 R} \cdot T_{2}\right)^{2}}, G=\left[2 \cdot J_{2 R} \cdot T_{1} \cdot c \cdot \varphi_{z}-J_{1 R} \cdot T_{2}^{2}\right]$.

The mathematical expression (9) gives the same value of the maximum torque in the elastic connection as the one from the literature [5], obtained by different solving of the phases of movement of masses through a clearance.

We may apply a simplified approach when we first observe the movement of a drive mass through a clearance, only within the acceleration period and an elastic connection without the presence of load, and then we can observe the movement of both masses. The movement of masses during the period of deceleration is not taken into account during this observation.

Both approaches give the same value for the maximum torque in the elastic connection between the masses.

We may apply the simplified approach which starts from the following equations for the movement of system masses shown in Fig. 7 [3]:

$J_{1 R} \cdot \ddot{\varphi}_{1}+b\left(\dot{\varphi}_{1}-\dot{\varphi}_{2}\right)+T_{\mathrm{C}}=T_{1}$, 
The Eqs. (10) represent the basis for the simulation of the dynamic behaviour of the system, shown in Fig. 7.

The impact of the clearance onto the load of the elastic connection may be included through the initial conditions while solving the Eq. (2).

Starting from the Eq. (2), with the following conditions: $t=0, T_{\mathrm{C}}=0, \mathrm{~d} T_{\mathrm{C}} / \mathrm{d} t=c \cdot \omega_{0}$, and if we ignore the damping $(b=0)$, we get the torque acting on the elastic connection [14]:

$$
T_{\mathrm{C}}(t)=T_{\mathrm{C} 0} \cdot(1-\cos (p \cdot t))+\frac{\omega_{0} \cdot c}{p} \cdot \sin (p \cdot t)
$$

In the mathematical expression (11), the second member originates from the impact of the clearance.

The angular speed of masses colliding with each other is:

$\omega_{0}=\sqrt{\frac{2 \cdot T_{1} \cdot \varphi_{z}}{J_{1}}}$.

If there is a clearance, the dynamic coefficient can be expressed as [14]:

$K_{\mathrm{D}}=1+\sqrt{1+\left(\frac{\omega_{0} \cdot c}{T_{\mathrm{C} 0} \cdot p}\right)^{2}}$.

The expression (13) shows that, with a constant external load, $K_{\mathrm{D}}>2$ for all the values originating from the impact of the clearance.

The presence of the clearance in the connected elements of some motor vehicle systems and industrial machines reduces their working and energy efficiency, and it is shown in the following examples. Due to the increase of a clearance between the excavator joints, its productivity decreases. According to [16], if the total clearance between joints is $3 \mathrm{~mm}$, the productivity of the excavator $(Э \mathrm{O}-4121)$ is decreased by $13 \%$. The increased clearance in the groove connection of the universal joint reduces a critical number of joint rotations during the vehicle exploitation [17].

\subsection{Dynamic coefficient in the function of load parameters}

On the basis of our research [2] we have given the dynamic coefficient $K_{\mathrm{D}}$ in the function of the operative mode parameters, construction parameters and system condition.

When there is no relative motion of one of the masses in relation to the other mass (drive mass in relation to the driven one or vice versa), i.e.:

$\varphi=$ const., $\dot{\varphi}=0$.

The elastic connection torque value is:

$T_{\mathrm{C}, \mathrm{st}}=\frac{J_{1 R} \cdot T_{2}+J_{2 R} \cdot T_{1}}{J_{1 R} \cdot J_{2 R}}$.
The dynamic coefficient value is determined on the basis of the following relation:

$K_{\mathrm{D}}=\frac{T_{\mathrm{C}, \max }}{T_{\mathrm{C}, \mathrm{st}}}$,

where $T_{\mathrm{C}, \max }$ is the maximum value of the torque in the elastic connection on the basis of the Eq. (9).

By introducing the relative parameters $\mu=J_{2 R} / J_{1 R}$ and $\theta=T_{2} / T_{1}$ from the Eq. (16) we get the equation for the dynamic coefficient, [2]:

$K_{\mathrm{D}}=1+\sqrt{1+\frac{1+\mu}{(\mu+\theta)^{2}} \cdot\left[2 \cdot \mu \cdot \frac{c \cdot \varphi_{z}}{T_{1}}-\theta^{2}\right]}$.

It should be pointed out that the mathematical expression (13), given in the reference literature [14], and the Eq. (17) which can be found in the paper by this author [2], give the same value of the dynamic coefficient $K_{\mathrm{D}}$, shown in the diagram in Fig. 8.

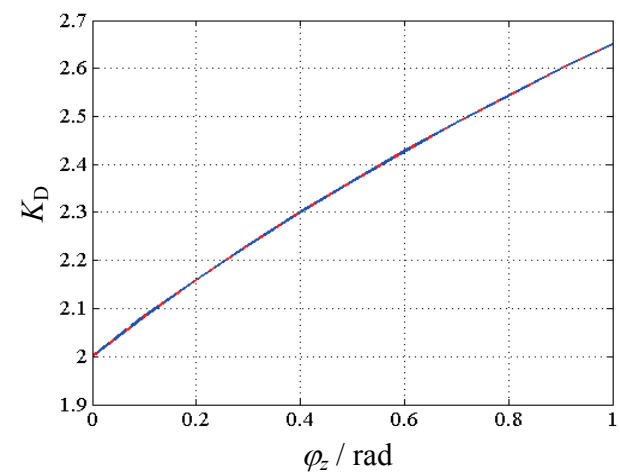

Figure 8 Dynamic coefficient change; blue line on the basis of Eq. (17); red line on the basis of Eq. (13); $\mu=31,12 ; \theta=0,058$

On the basis of the diagram in Fig. 8, it can be concluded that if there are no changes of system conditions and if it is an instant change with an instant increase of torque $T_{1}$, the dynamic coefficient is $K_{\mathrm{D}}=2$, as mentioned in the literature [14].

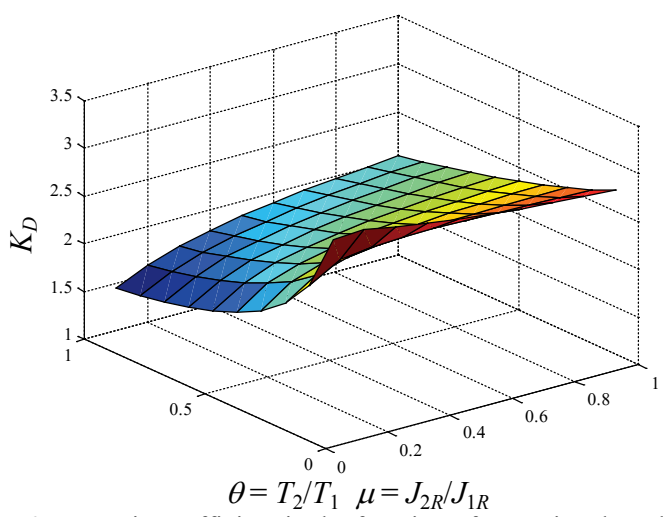

Figure 9 Dynamic coefficient in the function of operational mode and design parameters, for known system condition $\left(\varphi_{z}=0,7 \mathrm{rad}\right)$

In Fig. 9, for the known value of the condition change (clearance), we can see a $3 \mathrm{D}$ diagram of the dependence of the dynamic coefficient $K_{\mathrm{D}}$ on the relative parameters $\mu$ 
and $\theta$, and in Fig. 10 we can see the dependence of dynamic coefficient $K_{\mathrm{D}}$ as a function of one relative parameter, when the second one is invariable and when we know the value of the power transmission clearance.
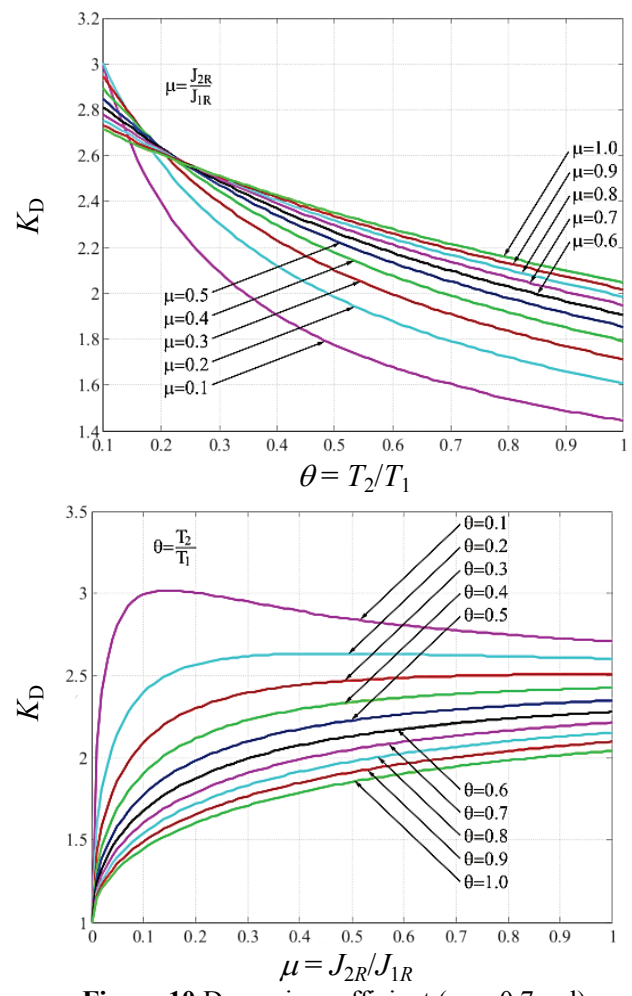

Figure 10 Dynamic coefficient $\left(\varphi_{z}=0,7 \mathrm{rad}\right)$

\subsection{Simulation model of movement of masses through the clearance}

For the elasto-inertial model shown in Fig. 6, we have adopted the following parameters: $T_{1}=5150 \mathrm{~N} \cdot \mathrm{m}, J_{1 R}=$ $2,66 \mathrm{~kg} \cdot \mathrm{m}^{2}, J_{2 R}=82.78 \mathrm{~kg} \cdot \mathrm{m}^{2}, c=4329 \mathrm{~N} \cdot \mathrm{m}, \varphi_{z}=0,698$ $\mathrm{rad},[2,3,12,15]$, and $T_{2}=100 \mathrm{~N} \cdot \mathrm{m}$, we performed the simulation of the movement of masses through the clearance using MATLAB-Simulink.

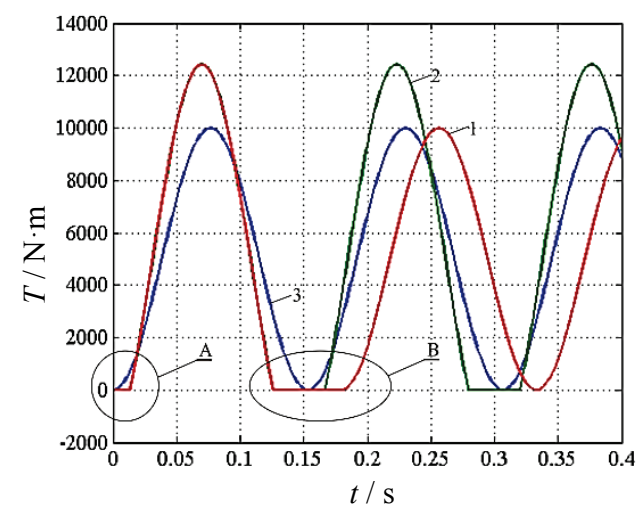

Figure 11 The torsion torque changes in the elastic connection; 1 - the curve obtained on the basis of the model of movement of masses through the clearance in five phases (in phase three the condition $b$ is met); $\mathrm{A}$ and $\mathrm{B}$ phases merger, 2 - the curve obtained on the basis of the simplified model where the clearance has been included through the initial conditions, Eq. (11); 3 - the curve represents the case when in the model no clearance is present $[2,15]$

In Fig. 11, we gave the curves representing the torsion torque changes in the elastic connection with the clearance - curves 1 and 2, and without the clearance curve 3 , together with the torsion torque change $\mathrm{M}_{1}$. It is necessary to point out that we have considered an ideal case where there are no other disturbances in the system.

On the basis of the diagram from Fig. 11, we can conclude the following:

- The maximum torsion torque value in the elastic connection with the clearance $\left(\varphi_{z}=0,698 \mathrm{rad}\right)$ curve 1 is $24,2 \%$ higher than for the case when no clearance is present - curve 3 ;

- The maximum torsion torque value in the elastic connection with the clearance obtained through the application of different models (curve 1 and curve 2) are of equal value;

- The curve amplitudes 2 and 3 do not change with time; curve 1; after the first maximum value amplitude, it continues its oscillation with the constant amplitude equal to curve 3 amplitude.

\section{Experimental research}

In accordance with laboratory-technical conditions, in order to confirm the data acquired from the simulation model of drive system, we have performed an experimental research on a specially prepared FORD Escort 1.6 D CL vehicle, at the Faculty of Mechanical Engineering in Podgorica.

Test vehicle was prepared in a manner which enabled us to install measuring devices, specifically:

- The modification of the axle-shaft and installation of measuring devices on both axle-shafts; right axleshaft was transformed into two parts which can be easily mounted onto one unit, with the possibility for the creation of angular clearance between them; mounting of connectors with sliding rings for signal transmission, which enabled us to measure axle-shaft torques, as in Figs. 12, 13 and 14,

- On the left and right axle-shaft we installed the measuring devices to measure torque, and necessary cables for a signal transfer through the sliding connector, Fig. 14, go through a wheel hub and to a dynamic strainmeter which is inside the vehicle.

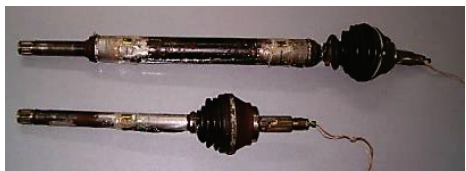

Figure 12 Axle-shaft with a groove and measuring devices for the torque measurement

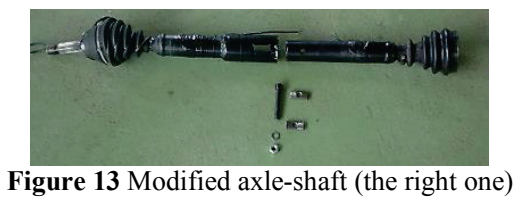

The measuring equipment for the conduction of the experiment consists of the DIGTAL Dynamic StrainMeter TMLDRA-101C, manufactured by Tokyo Sokki Kenkyjo-Japan, HBM movement sensor, HBM force sensor, type U9B/10 kN and U2A/200 kg, Fig. 15.

The research was carried out for different operational modes of the power system, i.e. we tested the changes 
during the transitional processes in power system until the constant movement of the vehicle was achieved, with the presence of the clearance $\varphi_{z}=0,17 \mathrm{rad}$ in the right axleshaft.

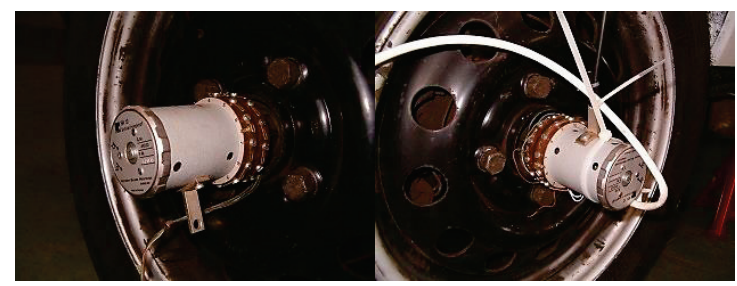

Figure 14 Connector for signal transfer to dynamic strain meter

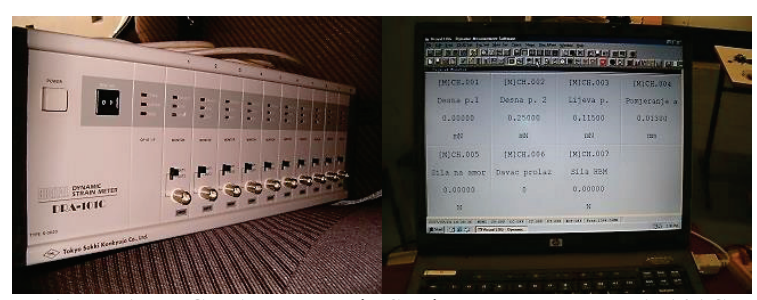

Figure 15 DIGITAL Dynamic Strain Meter TML DRA-101C

Some of the recorded torque changes on the axleshafts are shown on Figs. 16, 17, 18.

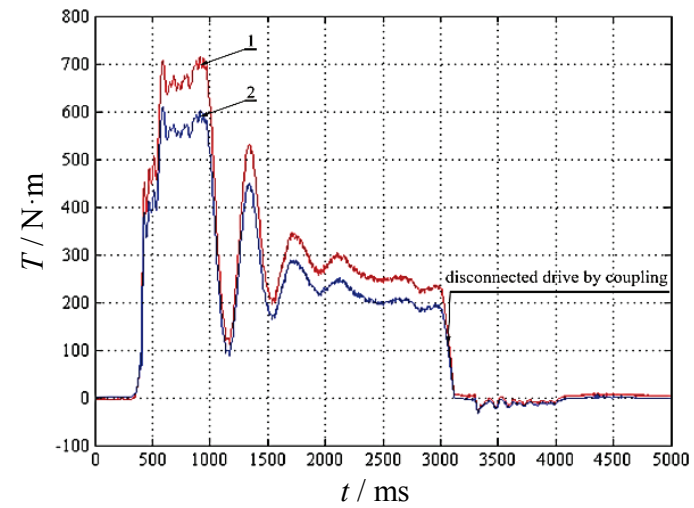

a)

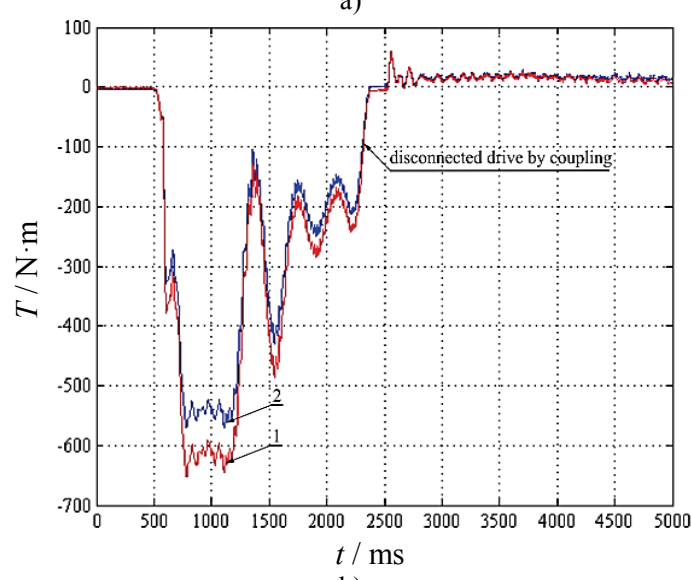

b)

Figure 16 The changes of torsion torque on the axle-shafts; a) vehicle at rest, through the sudden use of clutch starts its movement in the first gear; b) vehicle at rest, through the sudden use of clutch starts its movement in reverse; 1 - half shaft with clearance, 2 - half shaft with no clearance

In Fig. 16, we showed the charts of changes of torsion torque on the axle-shafts during the transitional operative regimes, i.e. during the start of the vehicle, injection of fuel to speed the engine and sudden use of the vehicle clutch [15].

On the basis of the chart in Figure 16, one can notice a significant increase of torsion torque during the transitional operative regimes on the axle-shaft with the clearance - curve no. 1 . On the shown charts, this increase is 15,9\%, in Fig. 16a, and $14 \%$ in Fig. 16b.

Furthermore, one can notice that the oscillatory processes in the system subside after a period of time due to existence of damping in the system.

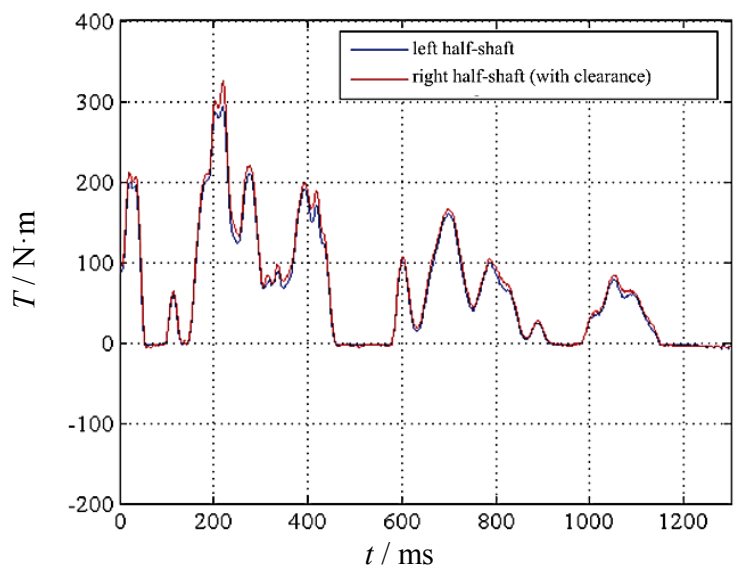

Figure 17 Torsion torque change (with fuel supply)

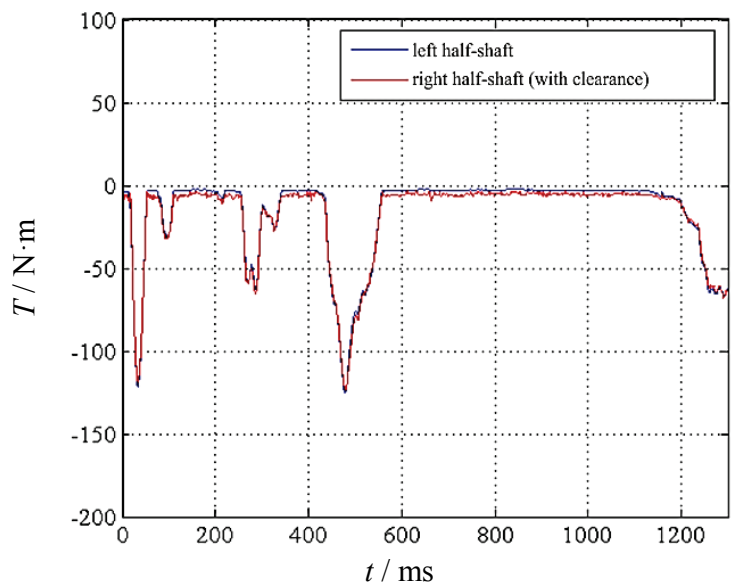

Figure 18 Torsion torque change (without fuel supply)

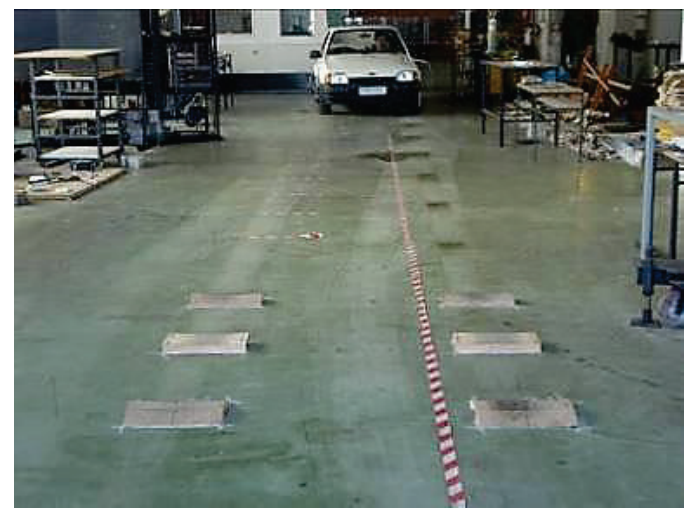

Figure 19 Test track

In Figs. 17 and 18, we showed charts of changes of the torsion torque on axle-shafts during the constant speed movement of the vehicle over a path, shown in Figs. 19 and 20 . 
On the basis of the charts in Figs. 17 and 18, one can notice that, during the usual movement, the existence of a clearance in the power transmission system elements is not significant for their load.

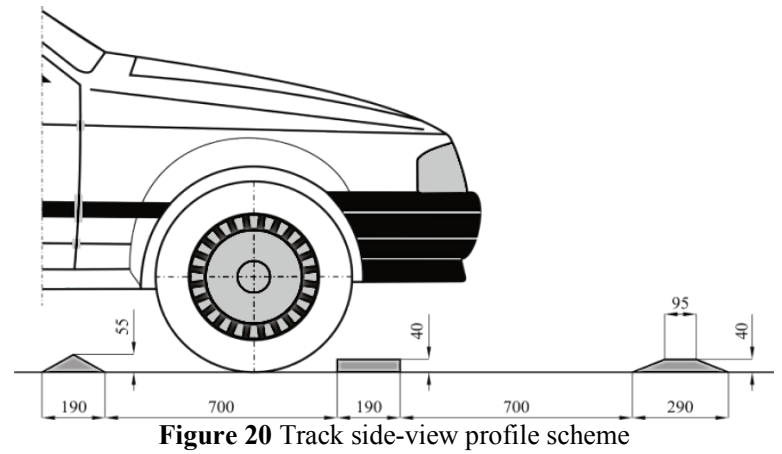

\section{Conclusions}

On the basis of the findings in this paper we can draw the following conclusions:

- The change of the system parameters, i.e. the clearance between the connections of the power transmission system does not affect the load of these elements in the usual operative modes,

- The influence of a clearance on the load of elements is very visible during the transitional operative modes while the masses are moving through the clearance,

- Apart from the condition change, the increase of the dynamic load is affected by a change of operational mode parameters, i.e. by a drive torque speed increase and an external load torque,

- On the basis of the theoretical analysis and experimental research, we concluded that dynamic loads during transitional operative regimes may be many times higher than static loads, if there is any clearance.

\section{References}

[1] Nauheimer, H.; Bertsche, B.; Ryborz, J.; Novak, W. Automotive transmissions - Fundamentals, selection, design and application, Springer, 2011.

[2] Damjanović, M. Procjena preostalog radnog vijeka sistema za prenos snage teretnih vozila (Estimation of the residual lifetime of truck power transmission system). // Doktorska disertacija, Univerzitet u Bogradu, Mašinski fakultet, Beograd, 2013.

[3] Damjanović, M.; Durković, R. Impact of clearance to the load of elements of transmission of motor vehicles. // XXII International Automotive Conference Science and Motor Vehicles 2009, JUMV 2009, University of Belgrade, Faculty of Mechanical Engineering / Belgrade, 2009. pp. 120.

[4] Mijajlović, M. R.; Marinković, M. Z.; Jovanović, Lj. M. Dinamika I optimizacija dizalica, Monografija, Mašinski fakultet u Nišu, Niš 2008.

[5] Scheffler, M.; Dresig, H.; Kurth, F. Fördertechnik Unstetigfördever 2, VEB Verlag tehonik, Berlin, 1977.

[6] Vladić, J.; Đokić, R.; Kljajin, M.; Karakašić, M. Modeling and simulations of elevator dynamic behavior, // Tehnicki vjesnik-Technical Gazette. 18, 3(2011), pp. 423-434.

[7] Jerman, B.; Hriber, A. Dynamics of the mathematical pendulum suspended from a moving mass. // Tehnicki vjesnik-Technical Gazette. 20, 1(2013), pp. 59-64.
[8] Blagojević, I.; Ivanović, G.; Janković S.; Popović, V. A model for gear shifting optimization in motor vehicles, // Transactions of FAMENA. 36(2012), pp. 51-66

[9] Blagojević, I.; Vorotović, G.; Ivanović, G.; Janković, S.; Popović, V. Energy efficiency improvement by gear shifting optimization. // Thermal Science. 17, (2013), pp. 91-105. DOI: 10.2298/TSCl120129035B

[10] Jovanović, J.; Tomović, R. Analysis of dynamic behavior of rotor-bearing system. // Journal of Mechanical Engineering Science. 228, 12(2013), pp. 2141-2161. DOI: 10.1177/0954406213516439

[11] Lukin, P.; Gasparyants, G.; Rodionov, V. Automobile chassis, Design and calculations, First published 1989, Revised from the 1984 Russian edition, English translation, Mir publishers, Moskva, 1989.

[12] Цитович, И. С.; Каноник, И. В.; Вавуло, В. А. Трансмиссии автомобилей, Наука и техника, Минск, 1979

[13] Альгин, В. Б.; Павловский, В. Я.; Поддубко, С. Н. Динамика трансмиссии автомобиля и трактора, Наука и техника, Минск, 1986.

[14] Колесник, Н. П. Расчеты строителъных кранов, Вищашкола, Киев, 1985.

[15] Damjanović, M.; Durković, R.; Bulatović, R.; Simović, S. Impact of clearance on the power transmission load in the process of movement of masses through the clearance. // XXIII International Automotive Conference Science and Motor Vehicles 2011, JUMV 2011, University of Belgrade, Faculty of Mechanical Engineering / Belgrade, 2011. pp. 110.

[16] Бухарин, Н. А.; Прозоров, В. А.; Щукин, М. М. Автмобили. Конструкция, нагрузочные режимы, рабочие процеси, прочносты агрегатов автмобиля, Машиностроение, Ленинградско отделение, Ленинград, 1973.

[17] Зорин, В. А. Основы долговечности строитлеьных и дорожных машин, Машиностроение, Москва, 1989.

[18] Beck, H.; Turschender, D. Selbstein-stellende regelung für losebenhaftete antriebssysteme, // Antrebstehnik. 8(2007), pp. 30-37.

[19] Бочаров, Н.Ф.; Цитович, И.С. Конструирование и расчет колесных машинвысокой проходимости, Машиностроение, Москва, 1983.

\section{Authors' addresses}

\section{Milanko Damjanović, PhD}

University of Montenegro,

Faculty of Mechanical Engineering,

Džordža Vašingtona bb,

81000 Podgorica, Montenegro

E-mail: milanko@ac.me

\section{Vladimir Popović, Professor PhD}

University of Belgrade,

Faculty of Mechanical Engineering,

Kraljice Marije 16,

11120 Beograd 35, Serbia

E-mail: vpopovic@mas.bg.ac.rs

\section{Sreten Simović, PhD}

University of Montenegro,

Faculty of Mechanical Engineering,

Džordža Vašingtona bb,

81000 Podgorica, Montenegro

E-mail: sretens@ac.me 